Mia Høj Mathiasson, ph.d.-studerende, Institut for Informationsstudier, Københavns Universitet.

\title{
Anmeldelse:
}

\section{DELTAGELSE som kunst- og kulturformidling}

DELTAGELSE som kunst- og kulturformidling, af Anne Scott Sørensen og Hjørdis Brandrup Kortbek, Samfundslitteratur (2018), 135 sider.

Er det virkelig deltagelse at trykke på en knap? Er det ikke blot interaktion? Disse spørgsmål affødes af mit første møde med bogen DELTAGELSE som kunst- og kulturformidling, da bogens forside prydes af et billede af den berømte og berygtede "kedsomhedsknap". Berømt, fordi denne knap i foråret 2018 blev landskendt som billedet på Nationalmuseets nyeste formidlingsstrategi. Berygtet, fordi meningerne om den var mildest talt delte: nogle mente den var genial, andre at den var banal. Ledsaget af bogens titel, med ordet "DELTAGELSE" i store typer, provokerer billedet af "kedsomhedsknappen" således allerede fra først ansats til en refleksion omkring kvaliteten af kunst- og kulturformidling, samt - ikke mindst - hvilken rolle deltagelse spiller heri.

Det er da også bogens hensigt; at stille spørgsmål til deltagelse som formidlingsform. Forfatterne bag bogen er de to kulturforskere Anne Scott Sørensen, professor i kulturstudier ved Institut for Kulturvidenskaber på Syddansk Universitet og Hjørdis Brandrup Kortbek, ph.d. og konsulent i Ledelsessekretariatet, By- og Kulturforvaltningen, Odense Kommune. Bogen udspringer af det fireårige forskningsprojekt "Mod et nyt kulturbegreb og nye former for kulturformidling", forkortet KULT, der fandt sted mellem 2014 og 2018. Spørgsmålet om den demokratiske værdi af deltagelse er rammesættende for bogen, med hvilken de to forfattere ønsker at bidrage til diskussionen om deltagelse som kulturpolitisk strategi og konkret formidlingspraksis i, eller i samarbejde med, offentlige kulturinstitutioner.

Bogen består af seks kapitler, der nærmer sig deltagelse som kulturpolitisk strategi og konkret formidlingspraksis fra henholdsvis et teoretisk, et historisk og et praksisorienteret perspektiv. I det første kapitel etableres bogens teoretiske ståsted gennem en introduktion til de tre nøglebegreber bruger-/borger-inddragelse, deltagelse og demokrati, samt begreberne radikalt demokrati, common(s), neoliberalisme, New Public Management og New Public Governance, der fungerer som rammesættende for forfatternes fortolkning og brug af nøglebegreberne. Sørensen og Kortbek skelner mellem inddragelse (engagement) og deltagelse (participation) ved at referere til det engelske firma Citizen Lab og deres skelnen mellem borgerinddragelse (citizen engagement) og borgerdeltagelse (citizen participation). Forskellen ligger $\mathrm{i}$ at inddragelse er initieret ovenfra og er formel $\mathrm{i}$ sin form, mens deltagelse er initieret nedefra og er uformel i sin form. Målet for begge former er dog det samme: 
at forbedre offentlige serviceudbydelser og politiske strategier. Sørensen og Kortbek er dog kritiske over for modellen, da den simplificerer processen og bygger på den naive antagelse at regeringen og borgerne på forskellige niveauer har eller vil kunne nå til samme mål. De vælger at anvende begrebet deltagelse gennem bogen uden det foranstillede "bruger" eller "borger". Her ville det være interessant at høre mere om hvordan diskursen har ændret sig og hvad begreberne "bruger" og "borger" hver især implicerer. Er de eksempelvis lige demokratiske?

Modsat Citizen Lab tager Sørensen og Kortbek afsæt i et andet og mere radikalt demokratibegreb. Deres brug af begrebet deltagelse skal ses i relation til dette radikale demokratibegreb, der er et alternativ til det liberale og såkaldte repræsentative demokrati og bygger på en mere direkte forståelse af demokrati inspireret af filosofferne Jacques Ranciére og Chantall Mouffe, samt kunst- og kulturteoretikerne Irit Rogoff og Nora Sternfeld. Gennem bogen vendes gang på gang tilbage til disse fire tænkere.

Det rammesættende begreb common(s) skal forstås som "det fælles" eller "en fælleshed" (side 93). I relation til kulturinstitutioner og kulturformidlere er common(s) et vigtigt begreb, da det helt konkret handler om, hvordan man balancerer mellem "det at tage vare på kulturarven for en generel offentlighed (...) og så det at tage vare på en given fællesheds ret, adgang og medbestemmelse (...)" (side 93-94). Begrebet neoliberalisme anvendes i bogen både som et (politisk-økonomisk) begreb og som et billede på en epoke. Hvor New Public Management, ifølge Sørensen og Kortbek, står for markedsliberale reformer, privatisering af det offentlige og velfærdsstramninger, står New Public Governance for indoptagelsen og inddragelsen af metoder fra det radikale demokrati og har således potentialet til at ændre ved den liberale økonomiske logik.

Som afslutning på første kapitel bruger forfatterne godt tre sider på at redegøre for "Hvad der er sagt og skrevet om deltagelse" (side 17) med referencer til blandt andre Sonia Livingstone (2013), Kirsten Drotner m.fl. (2011), Merete Sanderhoff (2014), Birgit Eriksson, Mette Houlberg Rung og Anne Scott Sørensen (2019), Nina Simon (2010), Shannon Jackson (2011), Claire Bishop (2011; 2013) og Nico Carpentier (2011). Det siger næsten sig selv, at denne redegørelse ikke kan blive andet end overfladisk når så mange - og så forskellige - teoretikere og skribenter skal på banen på mindre end tre sider. Desuden er gennemgangen af begrebet deltagelse (med undtagelse af medieteoretikerne Livingstone og Carpentier) primært baseret på kunstteori og museumsforskning. Her kunne man ønske sig, at forfatterne havde brugt mere tid og plads på at udfolde begrebet, der trods alt navngiver bogen, samt at give flere og mere opdaterede vinkler på dette komplekse fænomen.

En sådan vinkel udgøres dog af bogens andet kapitel, der har titlen "Deltagelse som kulturpolitisk strategi". Som baggrund for bogens historiske spor gennemgår Sørensen og Kortbek den kulturpolitiske udvikling i Danmark siden Kulturministeriets oprettelse i 1961. Her er fokus på den intime sammenhæng mellem deltagelse, kultur og demokrati, der har udgjort - og stadig udgør - det kulturpolitiske omdrejningspunkt. I de seneste år har outreach været rationalet bag den danske kulturpolitik, eksemplificeret af de to Reach out-kataloger fra henholdsvis 2008 og 2012. Sørensen og Kortbek bruger disse eksempler til at indkredse det grundelæggende paradoks som deltagelse som kulturpolitisk omdrejningspunkt afstedkommer: et overdrevet fokus på brugere (målgruppen for formidlingen) i stedet for på indholdet (kunst og kultur). Dette kan medføre en fare for at kunstog kultur reduceres til en biting. "Derved opstår det paradoks, at den kerneydelse, dvs. kunst- og kultur, der oprindeligt fremstod som garant for det demokratiske mål, fortoner sig (...) Deltagelsesstrategien risikerer altså i yderste konsekvens at skyde sig selv i foden" (side 33). Forfatterne refererer i denne sammenhæng til den Schweiziske kunsthistoriker Carmen Mörsch, der sætter det netop fremstillede paradoks ind i en større sammenhæng ved at pege på det "grundlæggende paradoks i og for institutionel kulturformidling i demokratiske samfund, nemlig det, at det er kulturformidlingens opgave at tilgodese det løfte, som den formidlede kunst eller kultur egentlig lover, men ikke kan holde - dvs. dét umiddelbart at være et (tilgængeligt) offentligt gode (for alle)" (side 34). Særligt interessant bliver det, når Sørensen og Kortbek følger op med Mörsch's bud på, hvordan det foromtalte paradoks kan blive produktivt: 
Muligheden for at gøre paradokset produktivt er, ifølge Mörsch, at finde i kulturformidlingen selv. Den ligger nemlig i det faktum, at kulturformidling, hvad enten den som praksis forstås som oversættelse fra et sprog til et andet eller overførelse fra et medium til et andet, altid i sig selv indebærer et gab - mellem det første og det andet, mellem selv og anden. Kulturformidlingen er simpelthen en performativ handling gennem hvilken, der altid tabes noget, men også lægges noget til, så en tredje ting opstår, der aldrig er identisk med udgangspunktet (side 35).

Den produktive mulighed er altså at finde i kulturformidlingen selv. Ifølge Mörsch er der ikke tale om "at opgive kunst, kultur og institution, men om at turde åbne op, slippe idéen om tilrettelagt deltagelse, der er et paradoks i sig selv, og tåle den risiko, men også de muligheder, der da følger med" (side 36). Det er, efter min mening, en vigtig pointe, at Mörsch her inkluderer institutionen da dennes rolle synes at mangle i Sørensen og Kortbeks fremstilling af kulturformidlingens grundlæggende paradoks. Som jeg ser det, er det hverken kunsten eller kulturen, der har afgivet et løfte om tilgængelighed og lige adgang, men institutionen og de bagvedliggende politiske målsætninger. Også pointen om, at det handler om at turde slippe ideen om tilrettelagt deltagelse, der er et paradoks i sig selv, er, efter min mening, vigtig at få med efter endt læsning.

I kapitel 3 behandler forfatterne "deltagelse som demokratisk eksperiment" med udgangspunkt i begreberne adgang, deltagelse (her benævnt agens), kollaboration/kollektiv, singularitet og ejerskab. Undervejs inddrager de gennem såkaldte "ekskurser" eksempler på "mere eller mindre vidtgående deltagelseseksperimenter" (side 7). Det handler om dialogisk-, eksperimentel- og kritisk eksperimentel kulturformidling og et grundlæggende fokus på hvad kulturformidlingen gør - med reference til Mörsch's pointe om kulturformidling som en performativ handling, hvortil der altid knytter sig et tab af kontrol.

Emnet for kapitel 4 er "deltagelse som institutionel formidlingspraksis". Her introducerer forfatterne deres model over forskellige deltagelsesformer og -modi (side 70). I modellen, der er formet som en firetakket stjerne, er de førnævnte begreber adgang, agens, kollektivitet/singularitet og ejerskab placeret i mellemrummene mellem stjernens takker. Derudover indgår begreberne samskaben, medbestemmen, samhandlen (agora) og medværen ud for stjernens fire spidser. Agens peger mod myndiggørelse/empowerment og stilles i modellen over for ejerskab, der peger mod social forandring. Ifølge forfatterne kan modellen bruges "som et redskab til både at planlægge og evaluere med" (side 69). Sørensen og Kortbek bruger resten af kapitel 4 på at forklare modellen ved inddragelse af yderligere eksempler på hybride deltagelsesformater. På trods af den grundige gennemgang er jeg stadig ikke overbevist om værdien af modellen eller dens anvendelsespotentialer. Begreberne er måske nok anvendelige, men placeringen omkring den firetakkede stjerne er mig et mysterium, ligesom jeg ikke kan afkode, hvorvidt de overfor-hinanden-stillede begreber skal forstås som modpoler eller blot som to forskellige måder, at nå det samme (?) mål.

I det femte kapitel inddrager Sørensen og Kortbek eksempler på deltagelse i kunst- og kulturprojekter i byen. Det sker blandt andet gennem en bevægelse fra "de kulturelle fyrtårne" som fx HEART i Herning, Museet for Søfart i Helsingør, DOKK1 i Aarhus og KUNSTEN i Aalborg. I modsætning til de etablerede fysiske institutioner fyrtårnene - bruger forfatterne "festen" som metafor for de midlertidige kulturbegivenheder, der finder sted i byens rum, såsom festivaller, optog og happenings. Sådanne festligheder er, ifølge Sørensen og Kortbek, "midlertidige fyrtårne" (side 89), der sprænger de institutionelle rammer og har potentiale for at åbne institutionerne op. I denne sammenhæng spiller begrebet common(s) en vigtig rolle: "Når commons bringes i anvendelse over for og i kunst- og kulturformidling i byen, så handler det ikke om at genfinde et tabt landsbyfællesskab, men derimod om at tænke i nye måder at gøre fælleshed på med plads til kontrovers, og med visse nødvendige normer for det fælles bedste" (side 94). Sagt på en anden måde er ideerne om mangfoldiggørelse og fælleshed, når det kommer til stykket, et opgør med et entydigt institutionelt ejerskab, samt mulighederne for at udfordre eksisterende forestillinger og magtstrukturer.

Bogens sjette og sidste kapitel har titlen "Demokratisk værdi - en ny værdikamp?". Her mødes det teoretiske, det historiske og det praksisorienterede spor $\mathrm{i}$ en afslutning, der både runder af og opstiller nye spørgsmål. Således vender Sørensen og Kortbek tilbage til deres påstand om, at vi er midt i en aktuel værdikamp i og omkring offentlig kultur eksemplificeret med "kedsomhedsknappen" og den debat der fulgte i kølvandet på dens 
lancering. Denne værdikamp er - i bogstavelig forstand - også "en kamp om, hvad værdi er, hvordan der kan tales om værdi, og hvordan værd(i)sættelsen kan og skal praktiseres" (side 107). Med reference til den amerikanske sociolog John Dewey og hans pointe om, at "al værd(i)sættelse udspringer af en formulering af et givet problem, der skal løses" (side 111) peger Sørensen og Kortbek tilbage på én af bogens grundlæggende problematikker: den multivalente og allestedsnærværende (e)valuering og "den måde, valuering praktiseres på, ikke mindst i kraft af nye, valuative medier" (side 20). Eksempler på denne (e)valueringspraksis kan findes i de nationale kulturvaneundersøgelser og -surveys baseret på "besøgstal og spørgeskemaer, der opererer ud fra bestemte klassifikationer og demografiske data" (side 112). Sådanne (e)valueringspraksisser har "afstedkommet et overvældende fokus på brugertypologi og dermed en deficitproblematik, dvs. det at forstå ikke-brug som en mangel og derved netop værdilade termen ikke-brugere (negativt). Det har igen gjort sit til at installere outreach som politisk og institutionel strategi. Siden 1964 har denne måde at evaluere kulturpolitik og -formidling på været dominerende og nærmest neutraliset "sådan, man (e)valuerer"'" (side 112). Som et alternativ til den måde hvorpå (e)valuering praktiseres i dag, introducerer Sørensen og Kortbek ideen om valuering som begivenhed, dvs. ikke som noget, der følger efter, men som noget der er indbygget i selve projektet/begivenheden/formidlingen etc. Dette er en inspirerende måde at betragte (e)valuering på og noget, der uden tvivl vil kunne anvendes af både nuværende og kommende praktikere, der ikke kan komme uden om at skulle tage stilling til spørgsmålet om (e)valuering og værd(i)sættelse.

Endelig vender Sørensen og Kortbek tilbage til kedsomhedsknappen, der har fungeret som "eksemplarisk omdrejningspunkt" for bogen og for de spørgsmål de to forfattere har ønsket at rejse. Det gode ved "kedsomhedsknappen" er, ifølge Sørensen og Kortbek, at den medførte en offentlig debat om, hvad kulturformidling er i dag. Således er den et godt billede på"debatten om deltagelse som en formidlingsform, der ændrer ved selve den måde, kulturinstitutionerne fungerer på" - en debat, der ifølge forfatterne "er vigtig for alle" (side 7). "Knapeffekten", som de kalder den, var udover at skabe debat også "at samle publikum - børn og voksne - om sig selv og derved opsuge den energi, publikum måtte møde med, eller som måtte gemme sig i de $\emptyset$ vrige rum og genstande" (side 119). Desuden argumenterer Sørensen og Kortbek for, at kedsomhedsknappen var "velgørende multivalent" som en gimmick, da den understregede "et opgør med den traditionsbestemte, museale autoritet og nærmest sakrale aura" (side 119).

Bogen præmis er "at skabe et radikalt demokratisk alternativ til den form for problematisering, som den aktuelle kontekst for offentlig kultur lægger op til, hvor deltagelse mere handler om at få så mange som muligt ind i de offentlige kulturinstitutioner end om hvordan og hvorfor" (side 118). Kommer Sørensen og Kortbek i mål med denne målsætning? Bogen igennem giver de i hvert fald nogle konkrete bud på, hvordan man som kulturinstitution og kulturformidler kan tænke anderledes og gribe opgaven anderledes an. Desuden foreslår forfatterne, at den hidtil dominerende kultur og formidlingspraksis udfordres af "en mere direkte demokratisk kultur og formidlingsform, hvor tidens påtrængende spørgsmål kan reflekteres og et rum for commoning etableres" (side 120). Dette er bestemt en udfordring, der bør tages op, men også en udfordring som mange kulturinstitutioner rundt om i landet - heriblandt mange folkebiblioteker - allerede har taget op.

Bogen igennem inddrages eksempler på deltagelseseksperimenter inden for kunst- og kulturformidling fra en lang række danske kulturinstitutioner. Her er eksempler fra museerne og den eksperimenterende kunstscene ikke overraskende - i flertal. Men hvor der inddrages omkring 20 eksempler fra museums- og galleriverdenen og 13 eksempler på kunst- og kulturformidlingstiltag enten online, i byrummet eller i relation til en etableret kulturinstitution, inddrages kun tre-fire eksempler fra teatrene og bibliotekerne og én enkelt reference til arkiverne. De mange eksempler fra museums- og kunstverdenen kommer til at skabe en uligevægtig repræsentation af det danske kulturinstitutionelle miljø. Særligt i forhold til begreberne demokrati og deltagelse er det ærgerligt, at eksemplerne, og dermed bogen, ikke når bredere ud. Eksempelvis ville forklaringerne af modellen i kapitel 4 flere steder være tydeliggjort med eksempler fra folkebiblioteker, teatre og arkiver. Det gælder blandt andet begreberne agens og samskabelse, kollaboration/kollektivitet og medbestemmen, samt medejerskab og samhandlen (agora). Inddragelse af flere eksempler fra et bredere kulturinstitutionelt felt kunne have højnet udsynet og ville - efter min mening - øge bogens anvendelsesmuligheder i praksis. 
Spørgsmålet om den demokratiske værdi af deltagelse er rammesættende for bogen. Der rejser sig et spørgsmål om der overhovedet er tale om demokratisering og - hvis ja - $i$ hvilken forstand der kan tales om demokratisering og hvordan dette spørgsmål i det hele taget kan stilles. Jeg sympatiserer i høj grad med forfatternes $\emptyset$ nske om at problematisere hvad man (e)valuerer og hvordan man (e)valuerer kunst- og kulturinstitutioner og deres formidlingspraksisser. Man kan måske, som Sørensen og Kortbek også gør, stille spørgsmålstegn ved det nye i denne værdikamp, da den har været en del af den danske kulturpolitiske agenda siden 1964. Men under alle omstændigheder er det en problematik og et spørgsmål, der er værd at (gen)rejse.

Hvorvidt bogens forfattere konkluderer, at "kedsomhedsknappen" er et godt eksempel på et kulturformidlingstiltag, der giver mulighed for demokratisk deltagelse er, efter endt læsning, uvist. Jeg kan ikke undgå at stå tilbage med en følelse af, at dette spørgsmål gerne måtte besvares tydeligt. Særligt når knappen er "det eksemplariske omdrejningspunkt" for bogen. Kedelig er den ikke, men om den ændrer fundamentalt og radikalt ved noget, kan diskuteres. På trods af dette leverer Sørensen og Kortbek ved at anvende billedet af kedsomhedsknappen som en - bevidst eller ubevidst - provokation et højaktuelt og højintellektuelt bidrag til en påtrængende debat, som man kun kan håbe flere kulturpolitikere, fagpersoner og ikke mindst borgere fremover vil deltage i og være med til at forme. 